\title{
One Step Back, Two Steps Forward
}

Viktor Z. Kazai

2019-11-26T12:44:48

At the end of May 2019, Prime Minister Viktor Orbán unexpectedly announced the Hungarian Government's intention to suspend the ongoing reform of the administrative court system. A few weeks later the National Assembly officially postponed the entry into force of the legislation for an indefinite period. This move was interpreted by some as a clear sign of the European institutions' successful efforts to stop the Hungarian Government's next attack on judicial independence. However, those who seriously thought that PM Orbán would ultimately abandon his plans because of some rule of law concerns voiced by European leaders clearly bet on the wrong horse.

First of all, the Hungarian Government never said it would completely "abandon" the administrative judicial reform. It only decided to suspend the process temporarily. Secondly, this move of PM Orbán was considered by many to be a strategic maneuver to enhance the chances of László Trócsányi, his candidate for EU commissioner. As Minister of Justice, Mr. Trócsányi was an ardent supporter of the administrative court reform which obviously did not look good on his resumé. However, once his nomination was definitely rejected, the incentive to exercise selfrestraint (even temporarily) disappeared.

On 12 November 2019, the Hungarian Government introduced an omnibus legislation which - according to the analysis of Amnesty International Hungary would extend political influence over the judiciary and guarantee judicial decisions favorable to the Government in politically sensitive cases even without setting up a separate administrative court system. Before discussing the details of the legislative proposal, let's take one step back. Although Hungarian NGOs and scholars have documented every single step of the administrative judicial reform process (see e.g. the publications of the Hungarian Helsinki Committee here or the numerous articles on Verfassungsblog), for those who have lost track of this saga here is a short timeline of the major events.

\section{Timeline of the administrative judicial reform saga}

Early 2016: the Hungarian Government revealed its plan to establish a separate administrative court system with its own apex court, the Administrative High Court. The main concern about the reform was that it would give significant influence over the administrative judiciary to the Minister of Justice.

December 2016: in the face of strong opposition the Hungarian Government pushed the legislative reform through parliament. Given the fact that at the material time Fidesz was a few votes shy of a qualified majority in the National Assembly, the bill was adopted in an ordinary legislative procedure by a simple majority of MPs. 
January 2017: upon the request of the President of the Republic, the Hungarian Constitutional Court annulled the legislative measures on the basis of formal unconstitutionality (i.e. the adoption of certain provisions would have required a twothirds majority of the parliamentary deputies).

May 2018: PM Orbán and his coalition returned for a third consecutive term with a two-thirds parliamentary majority and the Minister of Justice (László Trócsányi) announced that the Government would move forward with the administrative judicial reform.

June 2018: the Seventh Amendment to the Fundamental Law was adopted in order to create a clear constitutional basis for the administrative judicial reform. Hungarian human rights NGOs raised their concerns again.

September 2018: the European Parliament passed a resolution aimed at triggering the Article 7 procedure against Hungary and the administrative judicial reform figured among the breaches of EU values.

December 2018: the National Assembly adopted the judicial reform package in a chaotic legislative procedure as the parliamentary opposition tried to obstruct the process. Human rights NGOs and scholars remained concerned about the reform.

March 2019: the Venice Commission, requested by the Hungarian Government in November 2018, published its opinion on the legislative measures which was criticized by Hungarian scholars. The act was slightly modified in light of the Commission's criticism.

April 2019: the Hungarian Constitutional Court declared that the legislative process in which the judicial reform package had been adopted in December 2018 was constitutional.

June 2019: the Hungarian Constitutional Court concluded that the substance of the administrative judicial reform was in conformity with the Fundamental Law of Hungary.

July 2019: the Hungarian Government postponed the administrative court reform for an indefinite period of time.

November 2019: the new Minister of Justice (Judit Varga) announced that the Government had abandoned its plans to set up separate administrative courts, but it would pass legislation to speed up administrative court cases. The Government submitted an "omnibus bill" to the National Assembly which potentially extends political influence over the judiciary.

\section{Key points of the legislative proposal}

Believe it or not, Bill no. T/8016 on the amendment of certain acts related to the establishment of a single instance procedure of local government offices is actually a very interesting document. It is an omnibus legislation (or a so-called "salad 
act" according to the Hungarian terminology) which is supposed to modify several legislative acts in order to yield similar results as the original administrative court reform would have produced without setting up a separate judicial system. Let us summarize the key points:

Firstly, the law would entitle public authorities to file a constitutional complaint alleging the unconstitutional limitation of their competences and rights. It is easy to see the logic behind this provision: public authorities whose administrative decisions are reviewed (and potentially annulled) by ordinary courts could challenge the judicial decision before the Constitutional Court already packed by the Government. This idea does not come out of the blue. In Decision no. 23/2018. (XII. 28.) the Constitutional Court already acknowledged the Hungarian National Bank's right to file a constitutional complaint and concluded that the Supreme Court (Kúria) had violated the National Bank's right to a fair trial. Not surprisingly, with this rather "progressive" interpretation of the justiciability and standing criteria the Constitutional Court came to the rescue of the National Bank (led by Orbán's former Minister of Economy) in a politically sensitive case.

Secondly, the membership of the Constitutional Court and the ordinary judicial appointment would cease to be incompatible. This means, on the one hand, that the judicial mandate of justices of the Constitutional Court who served as ordinary judges before their election would only be suspended temporarily. Interestingly, the National Assembly has just filled the vacancy on the bench with Tünde Handó, former president of the National Office of the Judiciary who happens to be an ordinary judge. On the other hand, justices of the Constitutional Court would get the right to request to be nominated as an ordinary judge by the President of the Republic. In addition, the law would make it possible to appoint these justices to the position of chamber president at the Supreme Court after the expiry of their mandate at the Constitutional Court. In sum, given the fact that the current governing majority has unlimited control over the selection of Constitutional Court justices and that the majority of the bench is already loyal to the Government, opening an escape route from the CC to the Supreme Court obviously serves political purposes.

Besides these major changes, the bill also introduces some less spectacular but not less suspicious modifications. For example, the legislative proposal would modify the rules on case distribution and extend the mandatory national security vetting to a much larger number of judges without any justification. The existing administrative and labor law courts would cease to exist, and administrative law judges would be required to continue their work at the regional courts.

Finally, the law would strengthen the Supreme Court's power to tie the hands of lower court judges. Even though Hungary is a stock standard civil law jurisdiction with no system of legally binding judicial precedent, it would become the obligation of the judge to provide a written justification if her interpretation of the law differs from a previous decision delivered by the Supreme Court. An "unjustified deviation" could have a negative impact on her career. In order to fully appreciate the dangers of this idea, we need to remember that a few weeks ago the Supreme Court declared illegal the decision of a lower court judge who had sent six preliminary questions to the Court of Justice of EU, inter alia, about judicial independence in Hungary. 
What is more, disciplinary proceedings was initiated against the judge on the basis that his questions had violated the "dignity of the judiciary" (the procedure has been discontinued).

On the face of it, the bill seems to introduce some relatively minor or even technical changes. However, if we put these modifications in context, we can see that they would make it possible for the Government to enhance indirectly its political influence over administrative law cases. There are just too many coincidences. So, either the National Assembly is run by witches or the legislative reform is motivated by sheer political interests.

The bill is expected to be adopted by the National Assembly in the middle of December. Amnesty International Hungary and the Hungarian Helsinki Committee sent a letter to the Minister of Justice, Judit Varga, asking her to conduct a preliminary consultation procedure with the participation of professional organizations before the enactment of the law (a statutory obligation regularly disrespected by the Government). So if you would like to support the efforts of Hungarian NGOs to protect the independence of the last stronghold of the rule of law in Hungary, send a message to Judit Varga on Facebook (@VargaJuditMinisterofJustice), Twitter (@JuditVarga_EU) or directly to her email account (lakossag@im.gov.hu). 